\title{
Axial Energy Absorption of Kenaf Yarn Winding Cylindrical Composites
}

\author{
N.H Abdullah ${ }^{a}$, M.N Irwan ${ }^{b}$, A.E Ismail ${ }^{c}$ \\ Faculty of Mechanical and Manufacturing Engineering, Universiti Tun Hussein Onn Malaysia Parit \\ Raja, Batu Pahat, 86400 Johor, Malaysia

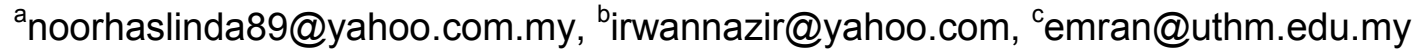

Keywords: Energy Absorption, filament winding, Kenaf Fiber Reinforced, composite, axial compression, failure collapse mechanism.

\begin{abstract}
This present work investigates the composites reinforced with kenaf fiber to fabricate the cylindrical tubes. According to the literature survey, it is found that lack of study research of producing the cylindrical composites with filament winding method using kenaf fiber. Therefore, this work used long fiber wetted with epoxy resin and then wound around the cylindrical mould. Three different winding angle orientations are used such as $0^{0}, 5^{\circ}$, and $10^{\circ}$. Then, the tubes are compressed Quasi-statically using a constant speed $1.5 \mathrm{~mm} / \mathrm{min}$ crosshead displacement. Force displacement curve are obtained and the area under the curve represented the energy absorption performance. It is found that the capability of energy absorption decrease when higher winding angles is used. At the same time, the collapse mechanisms are almost similar with different types of fiber orientations angle.
\end{abstract}

\section{Introduction}

For the preceding vehicle design, full metal is used as the energy absorbing element. However, since the mechanical properties of the metal itself, there is a weakness for the needs of lightweight materials and high energy absorbing capability. The result shows that the energy absorber made from steel mostly failure of bending and fracture, and hence leads to the absorption of energy produced is low [1]. In the automotive industry, the main thing that is taken into account for each vehicle component design is low cost, lightweight materials without sacrificing performance and meets sustainability aspects. This is why the composite material interest in the design of automotive structures for the mechanical properties of hard and brittle and has a characteristic strength to weight and stiffness to weight ratio, corrosion and fatigue resistance [2]. The magnitude and the rate of energy absorption is dependent on the specific material and structural characteristics of micro fiber/matrix and different orientations for the fabrication of a reinforced composite, for example a glass fiberreinforced composite materials using fabrication processes such as weaving, thread, random and so on [3]. Kenaf fiber, which is made from a plant called kenaf plant, is a plant species of the hibiscus family are shrubs that only require a period of about five months to harvest [4].

This study are conducted using a composite material made from kenaf fibers to reinforce a composite structure materials in different tubes which on different types of fiber orientation and dimensions of architectural forms used for the fabrication of composite materials research. Kenaf fiber reinforced composite tubular imposed axial compressive quasi-static verticals for optimum energy absorption due to the mechanism of the destruction of the compression process [5].

Recently, many studies have been carried out to determine the effects of various variables on energy absorption capability of composites material especially composites tubes such as geometry shape [6,7], fiber orientation stacking sequence and fiber reinforcement types [8,9]. In this paper, inclusive experimental work are implemented to study the response of energy absorption of kenaf fiber reinforced using filament winding cylindrical mould with different angle orientation such as $0^{0}, 5^{0}$ and $10^{0}$. 


\section{Theoretical background}

Composite materials have a much lower density compared to conventional materials. This provides important implications in the context of use for the composite strength and specific stiffness higher than conventional materials. The second implication is that composite products produced will have a lower weight than metal. Weight reduction is an important aspect in manufacturing industries such as automobile and aerospace. This is because it relates to fuel economy [10]. Figure 1 shows the experimental results where the load versus displacement of the tube facing the devastation stable. The curve starts with a linear region at the beginning of the line load is applied to the maximum peak load $\mathrm{P}$, as a result of failure on the part of the surface of the composite tube. Refer to number 1 in the figure. After laminar bending modes occur at peak load, steady disintegration of the region is reflected in the graph fluctuate irregularly shaped serrations [11].

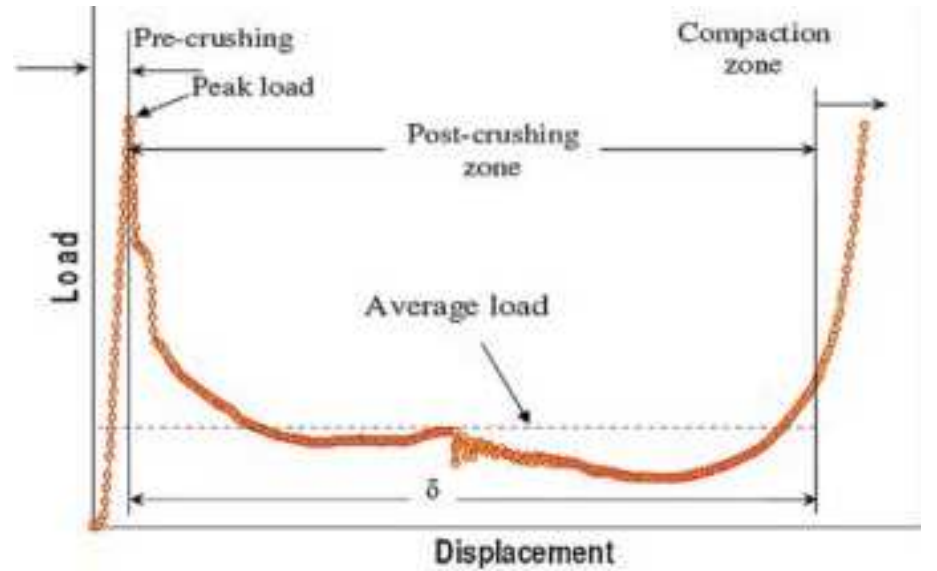

Figure 1 The experimental results where the load versus displacement of the tube facing the devastation stable.

Area under the force versus displacement curve gives the energy absorption for components specific to the loading direction, namely:

$$
\mathrm{E}(d)=\int_{0}^{d} f(d) d x
$$

The area shown in the figure 1of the displacement $d$ there is crush length, in the case of lightweight structural design, specific energy absorption (SEA) is an important design criterion, and is given by [12]:

$$
\operatorname{SAE}(d)=\frac{1}{m c} \int_{0}^{d} f(d) d x
$$

where $m$ is the mass of the component. If the absorption of energy $E(d)$ is divided by displacement $d$, the mean collapse load is obtained [12].

$$
\operatorname{Fm}(d)=\int_{0}^{d} f(d) d x
$$

Mean and initial collapse load are two design parameters of the most important in the design of energy absorption, as it is directly related to security agents that could protect the vehicle occupants [12]

\section{Experimental Work}

Long yarn kenaf fiber is used to wind around the cylindrical mould as in figure 2. Three winding angle orientation are used such as 0,5 , and 10 . Once the winding process is completed, the fibers are wetted with epoxy resin. Around 24 hours, the hardened composites tubes are removed from the 
cylindrical mould. The specimens are placed vertically at the UTM (universal testing machine) crosshead displacement, and then it is compressed Quasi-statically with constant speed $1.5 \mathrm{~mm} / \mathrm{min}$. The graph force vs. displacement is obtained automatically [15]. The areas under the curve represented the energy absorption or it can be calculated using Eq. 1[16,17]. Finally, the collapse mechanism is observed and related with the energy absorption [18].

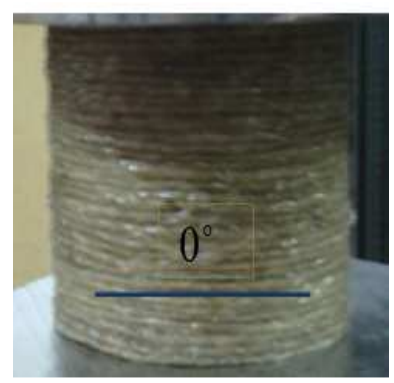

(a)

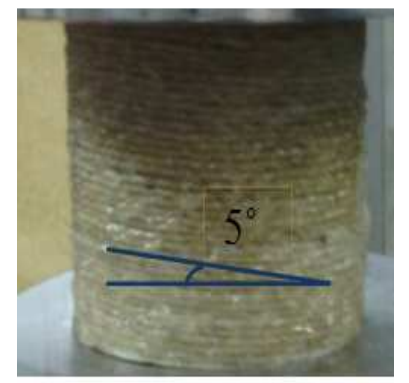

(b)

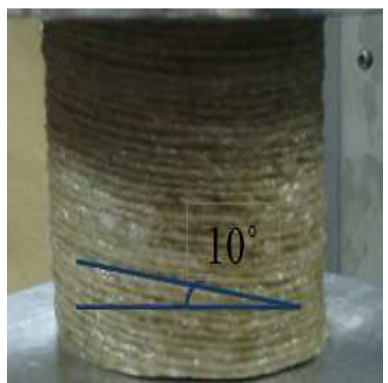

(c) Figure 2 Circumferential orientation angle (a) $0^{0}$ (b) $5^{0}$ (c) $10^{0}$

\section{Result and discussion}

Figure 3(a) shows the graph of energy absorption of yarn kenaf with $1 \mathrm{~mm}$ diameter with one winding of circumferential orientation angel $0^{\circ}, 5^{0}$ and $10^{\circ}$. This graph shows angle orientation that gives high impact of force-displacement is $5^{0}$, around 10 until $30 \mathrm{~mm}$ displacement the average result. Figure 3(b) shows the two layer of yarn winding with different angle orientation as shows as in figure; the angle that affects most of the result of force-displacement is $5^{0}$, around 10 until $30 \mathrm{~mm}$ displacement the average result. Figure 4 is the result of the layer kenaf winding with angle orientation such as $0^{0}, 5^{0}$, and $10^{0}$. The highest value of force vs. displacement obtained in the Figure 5 is the three layer of kenaf winding with angle orientation $5^{0}$.

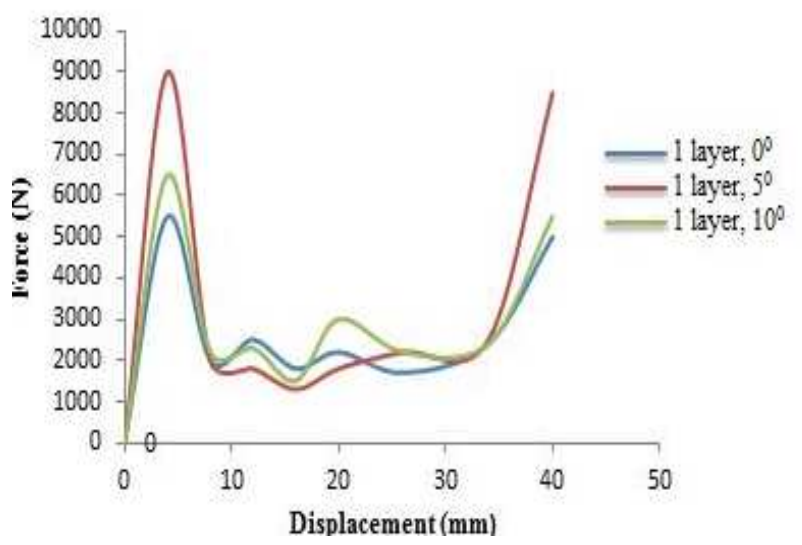

(a)

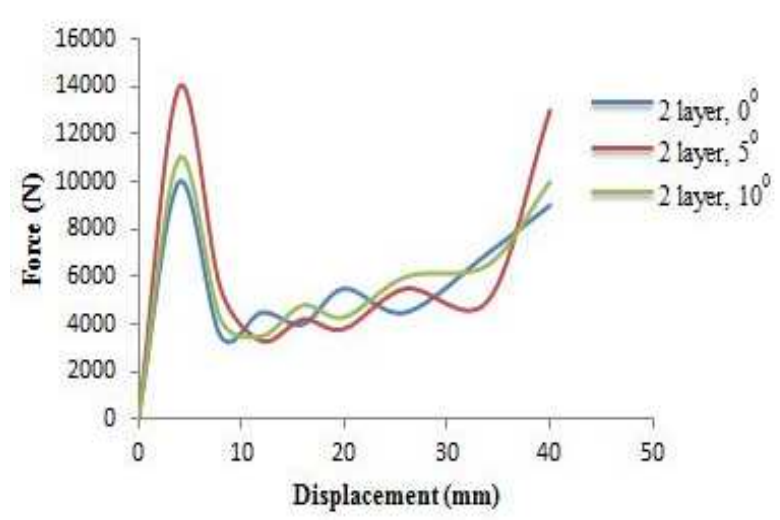

(b)

Figure 3 Force-displacement curves, (a) 1 layer and (b) 2 layers kenaf fiber for different fiber orientations. 


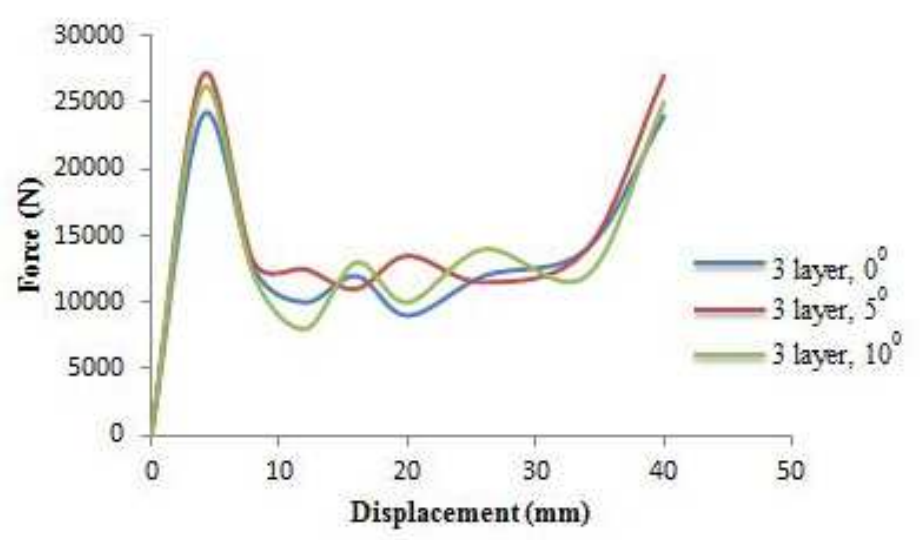

Figure 4 Three layers with different angle orientation kenaf winding

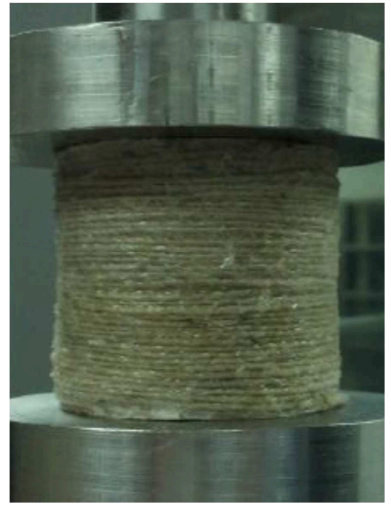

(a)

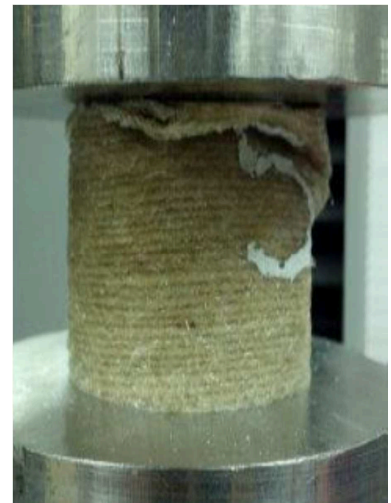

(b)

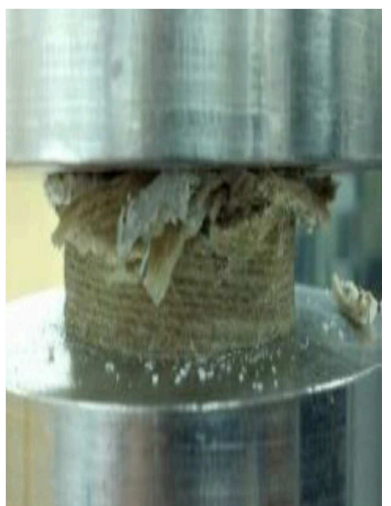

(c)

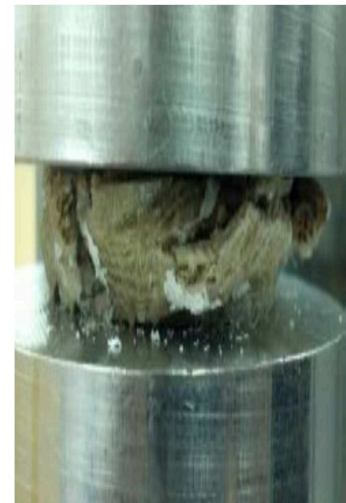

(d)

Figure 5 Collapse Modes for cylindrical tubes of one layer with $0^{0}$ fiber alignment.

Table 1 Results for cylindrical tubes

\begin{tabular}{cccc}
\hline $\begin{array}{c}\text { Sample } \\
\text { (Layers, Orientation) }\end{array}$ & $\begin{array}{c}\text { Energy absorption } \\
(\mathrm{kJ})\end{array}$ & Mass $(\mathrm{kg})$ & $\begin{array}{c}\text { Specific energy absorp- } \\
\text { tion }(\mathrm{kJ} / \mathrm{kg})\end{array}$ \\
\hline $1,0^{\circ}$ & 0.0776 & 0.03271 & 2.372 \\
$1,5^{\circ}$ & 0.0883 & 0.03265 & 2.704 \\
$1,10^{\circ}$ & 0.0861 & 0.03273 & 2.631 \\
$2,0^{\circ}$ & 0.1671 & 0.04168 & 4.009 \\
$2,5^{\circ}$ & 0.1770 & 0.04176 & 4.239 \\
$2,10^{\circ}$ & 0.1727 & 0.04182 & 4.130 \\
$3,0^{\circ}$ & 0.4007 & 0.05178 & 7.739 \\
$3,5^{\circ}$ & 0.4392 & 0.05192 & 8.459 \\
$3,10^{\circ}$ & 0.4071 & 0.05193 & 7.839 \\
\hline
\end{tabular}

\section{Conclusion}

Based on experimental works, the angle that gives the highest impact of energy absorption is at the angle of $5^{\circ}$ with 3 layers. Kenaf fiber has more particular strength compared to glass fiber. Kenaf fiber can substitute glass fiber to be used in the automotive industry to reduce the use of glass fibers. The use of natural materials can also reduce the harmful effects to the human. 


\section{Acknowledgements}

Authors acknowledge Universiti Tun Hussein Onn Malaysia (UTHM), Office for Research, Innovation, Commercialization and Consultancy (ORICC) and Ministry of Education Malaysia for sponsoring this work through Fundamental Research Grant Scheme (FRGS) vot. 1424.

\section{References}

[1] D.A Bailey. The Effect of Damage on the Energy Absorption Potential. Tesis phd. University of Nottingham; 2005.

[2] A.Chathbai. Parametric Study Of Energy Absorption Characteristics Of Rectangular Aluminium Tube Wrapped with E-Glass/Epoxy. Tesis Ijazah Sarjana Muda. Visvesvaraya Technological University of India; 2007.

[3] Anne Marie Harte, Norman A. Fleck, Michael F.Ashby. Energy absorption of foam-filled circular tubes with braided composite walls. European journal of mechanics - A/Solids. 19(1): 31$50 ; 2000$

[4] Mardimuadzam. Ringkasan-mengenai-tanaman. Retrieved on November 28, 2013, from http://mardimuadzam.blogspot.com/ringkasan-mengenai-tanamankenaf/2013/07html;2013

[5] Mohd Nazir Bin Irwan. Mekanisme kehancuran tiub silinder komposit diperkuat kenaf secara mampatan paksi. Tesis Ijazah Sarjana Muda. University Tun Hussein Onn Malaysia; 2014

[6] Palanivelu S, Van Paepegem W, Degrieck J, Kakogianis D, Van Ackere J, Van Hemelricjk D, Et Al. Comparative study of the quasi-static energy absorption of small-scale composites tubes with different geometrical shapes for use in sacrificial cladding structures. Polym. Test 2010;29:381-96

[7] Eshkoor RA, Oshkovr SA, Sulong AB, Zulkifli R, Ariffin AK, Azhar CH. Effect of trigger configuration on the crashworthiness characteristic of natural silk epoxy composite tubes. Composites Part B 2013;55:5-10.

[8] Ochelski Stanislaw, Gotowicki Pawel. Experimental assessment of energy absorption capabitility of carbon-epoxy and glass-epoxy composites. Compos Struct 2009;87:215-24

[9] Eksi, Kapti Akin O, Genel Kenan. Buckling behavior of fiber reinforced plastic-metal hybrid-composites beam. Mater des 2013;49:130-8

[10] Khairel Rafezi Ahmad, Mohd Mustafa Al-Bakri Abdullah, Che Mohd Ruzaidi Ghazali, Shamsul Baharin Jamaluddin, Mohamed Faisal Mohamed Nor, \& Alida Abdullah. Pengenalan Bahan Komposit. Tesis Ijazah Sarjana Muda. Universiti Malaysia Perlis; 2011

[11] Courtaeu. Investigating the crashworthiness characteristics of carbon fiber/epoxy tubes. University of utah;2011

[12] Heryemer. On the crashworthiness of foam-filled ultralight automotive structures. University of toroton; 2000

[13] Elfetori F. Abdewi, Shamsuddeen Sulaiman ,A.M.S. Hamouda, E.Mahdi. Quasi-static axial and lateral crushing of radial corrugated composite tubes. Thin-Walled Structures 46(3): 320-332;2008.

[14] A.E Ismail, M.H Zainulabidin, M.N Roslan, A.L.M Tobi, N.H.M Nor. Effect of velocity on the impact resistance of woven jute fiber reinforced composites. Applied Mechanics and Materials (2014) 465:1277-1281.

[15] A.E Ismail, Effect of foam density and wall thickness interactions on the energy absorption performances. Applied Mechanics and Materials (2013) 315:665-669. 
[16] S.H Masran, A.E Ismail, M.F Marian, A study of energy absorption performances of pultruded composites under quasi-static compressive loadings. Applied Mechanics and Materials (2014) 465:662-666.

[17] A.E Ismail, M.K Awang, M.H Sa'at, Tensile strength of natural fiber reinforced polyester composite, AIP Conf. Proc. 909 (2007) 174-179.

[18] M.N Roslan, A.E Ismail, M.Y Hashim, M.H Zainulabidin, S.N.A Khalid, Modelling analysis on mechanical damage of kenaf reinforced composite plates under oblique impact loadings, Applied Mechanics and Materials 465 (2014) 1324-1328. 